\title{
Zakres uprawnień poselskich wobec Komisji Nadzoru Finansowego w świetle art. 16, 19 i 20 ustawy o wykonywaniu mandatu posła i senatora ${ }^{1}$
}

The scope of Deputies' powers concerning the Polish Financial Supervision Authority in the light of Articles 16, 19 and 20 of the Act on the Exercise of the Mandate of a Deputy or Senator: According to the author of the opinion, a legal basis of control activities executed individually by the Deputy with regard to the Polish Financial Supervision Authority may be found in Article 16 of the Act on the Exercise of the Mandate of a Deputy or Senator. It creates an opportunity to obtain "information and explanations on matters resulting from the performance of Deputy's duties". Consequently actions taken by Deputies should be related to a collegial activity of the Sejm or its bodies. In the context of Articles 19 and 20 of the above act the author points out that the Polish Financial Supervision Authority is not a governmental administration body. Thus it stays outside of the scope of the Deputies' intervention.

Keywords: Deputy, mandate, Polish Financial Supervision Authority

Słowa kluczowe: poseł, mandat, Komisja Nadzoru Finansowego

Ekspert ds. legislacji BAS - wojciech.sypniewski@sejm.gov.pl • https://orcid.org/0000-0002-7704-5042

\section{Przedmiot opinii}

Przedmiotem opinii jest analiza zakresu uprawnień poselskich wobec Komisji Nadzoru Finansowego wynikających z art. 16, 19 i 20 ustawy o wykonywaniu mandatu posła i senatora.

1 Opinia prawna na temat zakresu uprawnień poselskich wobec Komisji Nadzoru Finansowego $w$ świetle art. 16, 19 i 20 ustawy o wykonywaniu mandatu posła i senatora sporządzona 27 grudnia 2018 r. na zlecenie posła Klubu Parlamentarnego Platforma Obywatelska - Koalicja Obywatelska; BAS-WAKiU 2781/18. 


\section{Status ustrojowy Komisji Nadzoru Finansowego}

Punktem wyjścia dla odpowiedzi na pytanie o zakres kontrolnych uprawnień poselskich wynikających z ustawy z 9 maja 1996 r. o wykonywaniu mandatu posła i senatora (t.j. Dz.U. 2018, poz. 1799, ze zm.) jest ustalenie statusu ustrojowego Komisji Nadzoru Finansowego.

W świetle ustawy z 21 lipca 2006 r. o nadzorze nad rynkiem finansowym (t.j. Dz.U. 2018, poz. 621, ze zm.; dalej: u.n.r.f.) Komisja Nadzoru Finansowego (dalej: KNF lub Komisja) jest organem właściwym w sprawach nadzoru nad rynkiem finansowym, a nad jej działalnością nadzór sprawuje Prezes Rady Ministrów (art. 3 ust. 2 i 3). Skład Komisji tworzy przewodniczący, dwóch zastępców przewodniczącego i dziewięciu członków, którymi są: minister właściwy do spraw instytucji finansowych albo jego przedstawiciel, minister właściwy do spraw gospodarki albo jego przedstawiciel, minister właściwy do spraw zabezpieczenia społecznego albo jego przedstawiciel, Prezes Narodowego Banku Polskiego albo delegowany przez niego członek Zarządu Narodowego Banku Polskiego, przedstawiciel Prezydenta Rzeczypospolitej Polskiej, przedstawiciel Prezesa Rady Ministrów, przedstawiciel Bankowego Funduszu Gwarancyjnego, przedstawiciel Prezesa Urzędu Ochrony Konkurencji i Konsumentów, przedstawiciel ministra członka Rady Ministrów właściwego do spraw koordynowania działalności służb specjalnych, a jeżeli nie został wyznaczony - przedstawiciel Prezesa Rady Ministrów (art. 5 ust. 1 i 2 u.n.r.f.). Przewodniczącego Komisji powołuje Prezes Rady Ministrów na pięcioletnią kadencję, a zastępców przewodniczącego powołuje i odwołuje Prezes Rady Ministrów na wniosek przewodniczącego Komisji (art. 7 i 9 u.n.r.f.). Prezes Rady Ministrów odwołuje przewodniczącego Komisji przed upływem kadencji wyłącznie w przypadku wystąpienia jednej z sytuacji wymienionych $\mathrm{w}$ ustawie, tj. prawomocnego skazania za umyślne przestępstwo lub przestępstwo skarbowe, rezygnacji ze stanowiska, utraty obywatelstwa polskiego lub utraty zdolności do pełnienia powierzonych obowiązków na skutek długotrwałej choroby, trwającej dłużej niż 3 miesiące. Niedopuszczalne jest odwołanie przewodniczącego Komisji z powodu negatywnej oceny działalności jego lub KNF, naruszania prawa albo nierealizowania polityki rządu (art. 8 ust. 1 u.n.r.f.). KNF i przewodniczący Komisji wykonują swoje zadania przy pomocy Urzędu KNF (art. 10 u.n.r.f.).

Kwestia usytuowania ustrojowego KNF stała się przedmiotem analizy Trybunału Konstytucyjnego w wyroku z 15 czerwca 2011 r. (sygn. akt K 2/09). Oceniając zgodność przepisów ustawy wyłączających pracowników Urzędu Komisji Nadzoru Finansowego z korpusu służby cywilnej z art. 153 ust. 1 Konstytucji, sąd konstytucyjny stanął przed koniecznością odpowiedzi na pytanie, czy KNF jest organem administracji rządowej. W swoim wcześniejszym orzecznictwie Trybunał przyjął stanowisko, że z treści art. 153 Konstytucji wynika obowiązek wprowadzenia korpusu służby cywilnej we wszystkich 
urzędach administracji rządowej $^{2}$. Kwalifikacja KNF jako organu administracji rządowej musiałaby prowadzić do konkluzji, że przepisy wyłączające pracowników Urzędu KNF z korpusu służby cywilnej są niezgodne z art. 153 ust. 1 Konstytucji.

Sąd konstytucyjny zauważył, że ustawa zasadnicza nie definiuje terminu „administracja rządowa”. Z treści przepisów Konstytucji dotyczących Rady Ministrów i Prezesa Rady Ministrów wynika, że Rada Ministrów jest organem, który stoi na czele i kieruje administracją rządową. Organy administracji rządowej mogą podlegać zarówno Prezesowi Rady Ministrów, jak i ministrom, czyli organom, które mają przyznane ustawowo kompetencje w tym zakresie (art. 148 pkt 4, 5 oraz art. 149 ust. 1 zdanie pierwsze Konstytucji). W ocenie Trybunału Konstytucyjnego: konstytucyjnym kryterium uznania określonego organu za należacy do struktury administracji rzadowej jest sprawowanie przez Rade Ministrów - w sposób bezpośredni lub pośredni, tj. przez Prezesa Rady Ministrów lub ministra - kierownictwa nad działalnościa tego organu (art. 146 ust. 3 Konstytucji). $Z$ powyższego wynika, że używany w Konstytucji termin „administracja rzadowa" odnosi się do struktury organizacyjnej pozostającej w określonych powiazaniach $z$ Rada Ministrów, Prezesem RM albo ministrami. W skład tej struktury wchodza organy administracji rządowej oraz urzędy, rozumiane jako jednostki organizacyjne, będace aparatem pomocniczym, za pomoca którego organy wykonuja swoje zadania i realizuja kompetencje. W tym kontekście Trybunał nawiązał do swojego wcześniejszego orzecznictwa, w którym uznał, że: do uznania jakiegoś urzędu za urząd administracji rzadowej potrzebne jest równoczesne spetnienie dwóch warunków: wykonywanie zadań mających charakter administracji publicznej oraz umiejscowienie w tym segmencie aparatu państwowego, na czele którego stoi rzą, czyli Rada Ministrów. [...] urzędami administracji rzadowej, o których mowa $w$ art. 153 ust. 1 Konstytucji, sq urzędy administracji organizacyjnie i funkcjonalnie podporzadkowane Radzie Ministrów jako całości, Prezesowi Rady Ministrów, poszczególnym ministrom albo wojewodom (bezpośrednio lub za pośrednictwem innych organów podległych organizacyjnie i funkcjonalnie tym podmiotom $)^{3}$.

Zdaniem sądu konstytucyjnego: o zaliczeniu danego organu do administracji rządowej decyduje w świetle Konstytucji poddanie tego organu „kierownictwu” oraz „koordynacji i kontroli” Rady Ministrów, przy czym funkcje te moga sprawować także Prezes RM i ministrowie. Przepisy ustawowe stanowiq, że organy te podlegaja lub sq nadzorowane przez Prezesa RM lub ministrów kierujacych działami administracji rzadowej. ${ }^{4}$. Po przeprowadzeniu szczegółowej analizy przysłu-

2 Zob. wyrok z 12 grudnia 2002 r., sygn. akt K 9/02; wyrok z 13 listopada 2003 r., sygn. akt K 51/02.

3 Wyrok TK z 28 kwietnia 1999 r., sygn. akt K 3/99.

4 Wyrok TK z 15 czerwca 2011 r., sygn. akt K 2/09. 
gujących Prezesowi Rady Ministrów oraz poszczególnym ministrom środków oddziaływania na KNF, Trybunał uznał, że mają one charakter ograniczony. Sprowadzaja się do określenia struktury organizacyjnej Komisji (nadanie statutu Urzędu KNF), zasad wynagradzania Przewodniczącego Komisji i jego zastępców oraz pracowników Urzędu KNF i przyznawania im nagród, a także powołania Przewodniczącego i jego zastępców. Prezes RM nie ma $w$ istocie kompetencji kontrolnych nad Komisja, ponieważ ustawy nie upoważniaja go do żądania informacji, tak jak w przypadku organów administracji rzq̨dowej, a ustawa n.r.f. [o nadzorze nad rynkiem finansowym - przyp. W.O.-S.] nie daje mu możliwości reagowania na roczne sprawozdanie KNF. Prezes $R M$ nie ma kompetencji do podjęcia decyzji o odwołaniu Przewodniczacego KNF poza wyraźnie przewidzianymi w ustawie przypadkami niezwiązanymi z negatywna ocena działalności Przewodniczącego. Wobec niewymienienia Urzędu KNF w katalogu zamieszczonym w art. 33 a ust. 1 ustawy o działach, nie jest dopuszczalne kierowanie do Komisji wiążacych wytycznych i poleceń na podstawie art. $33 b$ ust. $1 \mathrm{w}$ związku $z$ ust. 2 ustawy o działach [...]. Prezes RM nie ma tym samym możliwości oddziaływania na funkcjonowanie $K N F^{5}$.

W konkluzji sąd konstytucyjny stwierdził, że KNF nie jest podporządkowana Prezesowi Rady Ministrów ani ministrom, jej status charakteryzuje się znaczną samodzielnością i niezależnością, większą niż w przypadku organów regulacyjnych określonych w ustawach jako centralne organy administracji rządowej. W obecnym kształcie przepisów dotyczących Komisji nie można uznać, że została spetniona konstytucyjna przesłanka uznania tego organu za należacego do struktury administracji rzadowej ${ }^{6}$. W ocenie Trybunału Konstytucyjnego: Komisja Nadzoru Finansowego jest szczególnym organem administracji publicznej - państwowej, ale usytuowanym poza struktura administracji rządowej ${ }^{7}$.

Należy podkreślić, że liczne zmiany, którym od 2011 r. podlegała ustawa o nadzorze nad rynkiem finansowym, nie wiązały się z taką modyfikacją statusu ustrojowego KNF, która prowadziłaby do dezaktualizacji przytoczonych ustaleń Trybunału Konstytucyjnego. Podsumowaniem tej części opinii jest zatem pogląd, że w świetle wyjaśnień sądu konstytucyjnego - niezależnie od oceny ich trafności - KNF jest organem nienależącym do systemu organizacyjnego Rady Ministrów, pozostającym poza strukturą administracji rządowej.

\footnotetext{
Ibidem.

Ibidem.

Ibidem. Zob. także A. Jurkowska-Zeidler, Status prawny Komisji Nadzoru Finansowego jako organu administracji publicznej w świetle wyroku Trybunału Konstytucyjnego $z$ dnia 15 czerwca 2011 r., „Gdańskie Studia Prawnicze” 2012, nr 2 s. 143; M. Ochwat, Status prawny Komisji Nadzoru Finansowego, „Monitor Prawa Bankowego” 2015, nr 7-8, s. 44 .
} 


\section{Uprawnienia poselskie wynikające z art. 16, 19 i 20 ustawy o wykonywaniu mandatu posła i senatora}

1. Ustawa z 9 maja 1996 r. o wykonywaniu mandatu posła i senatora (Dz.U. 2018, poz. 1799; dalej: u.w.m.p.s.) przyznaje posłom kilka odrębnych uprawnień kontrolnych. W rozdziale 3 ustawy zatytułowanym „Prawa i obowiązki posłów i senatorów w Sejmie i w Senacie” zawarty jest art. 16, który przewiduje, że: [p] osłowie i senatorowie maja prawo uzyskiwać od członków Rady Ministrów oraz przedstawicieli właściwych organów i instytucji państwowych i samorzadowych informacje $i$ wyjaśnienia $w$ sprawach wynikających $z$ wykonywania obowiązów poselskich lub senatorskich (ust. 1). W myśl art. 16 ust. 2 u.w.m.p.s.: Członkowie Rady Ministrów oraz przedstawiciele właściwych organów i instytucji państwowych i samorzadowych, organizacji społecznych, zakładów i przedsiębiorstw państwowych i samorządowych, spółek prawa handlowego z udziałem państwowych lub komunalnych osób prawnych sa obowiązani przedstawiać informacje i wyjaśnienia na żadanie stałych i nadzwyczajnych komisji sejmowych i senackich, w sprawach będacych przedmiotem ich zakresu działania. Z uprawnieniem komisji sejmowych korespondują zasady określone w art. 153 regulaminu Sejmu, które przewidują, że: na żądanie prezydium komisji ministrowie oraz kierownicy naczelnych organów administracji państwowej, a także kierownicy innych urzędów i instytucji państwowych sa obowiazani przedstawiać sprawozdania i udzielać informacji oraz uczestniczyć w posiedzeniach komisji, na których rozpatrywane sa sprawy dotyczace ich zakresu działania. Osoby te moga upoważnić pisemnie swego przedstawiciela do udziału $w$ posiedzeniu.

W rozdziale 4 u.w.m.p.s. „Inne prawa i obowiązki posłów i senatorów” zawarty jest art. 19 ust. 1 ustanawiający tzw. prawo dostępu do informacji ( $W w y$ konywaniu mandatu poseł lub senator ma prawo, jeżeli nie narusza dóbr osobistych innych osób, do uzyskiwania informacji i materiatów, wstępu do pomieszczeń, $w$ których znajduja się te informacje i materiały, oraz wgladu $w$ działalność organów administracji rządowej i samorządu terytorialnego, a także spółek $z$ udziałem Skarbu Państwa oraz zakładów i przedsiębiorstw państwowych i samorządowych, $z$ zachowaniem przepisów o tajemnicy prawnie chronionej), oraz art. 20 ustanawiający tzw. prawo do interwencji (Poseł lub senator ma prawo podjać $-w$ wykonywaniu swoich obowiązków poselskich lub senatorskich - interwencję w organie administracji rządowej $i$ samorzadu terytorialnego, zakładzie lub przedsiębiorstwie państwowym oraz organizacji społecznej, a także $w$ jednostkach gospodarki niepaństwowej dla załatwienia sprawy, która wnosi we własnym imieniu albo w imieniu wyborcy lub wyborców, jak również zaznajamiać się z tokiem jej rozpatrywania).

Rozważania dotyczące możliwości zastosowania wymienionych wyżej instrumentów kontrolnych wobec KNF poprzedzać musi konstatacja, że przepisy te $\mathrm{w}$ niemal niezmienionym kształcie przeniesione zostały do ustawy o wykonywa- 
niu mandatu posła i senatora z ustawy z 31 lipca 1985 r. o obowiązkach i prawach posłów i senatorów. Ich treść normatywna z trudem daje się uzgodnić z ograniczeniami funkcji kontrolnej Sejmu wynikającymi z Konstytucji RP z 1997 r., zaś formułowane w doktrynie postulaty modyfikacji tych przepisów są konsekwentnie ignorowane przez ustawodawcę.

2. Analiza zakresu przedmiotowego uprawnienia zawartego w art. 19 ust. 1 u.w.m.p.s. wskazuje, że prawo dostępu do informacji, o którym mowa w tym przepisie, odnosi się do: organów administracji rządowej i samorządu terytorialnego, a także spółek $z$ udziałem Skarbu Państwa oraz zakładów i przedsiębiorstw państwowych i samorządowych. Zbiór podmiotów, na których ciążą obowiązki związane z omawianym uprawnieniem poselskim, nie obejmuje zatem KNF, która nie jest organem administracji rządowej, a jej status nie odpowiada charakterystyce ustrojowej pozostałych podmiotów wymienionych w art. 19 ust. 1 u.w.m.p.s. Podobnie należy ocenić możliwość wykorzystania art. 20 ust. 1 u.w.m.p.s dla skontrolowania KNF w ramach indywidualnej działalności poselskiej. Również w tym wypadku pozycja prawna KNF sytuuje ten organ poza zakresem zbioru potencjalnych adresatów interwencji poselskiej.

3. Bardziej złożona jest analiza możliwości podjęcia czynności kontrolnych na podstawie art. 16 ust. 1 u.w.m.p.s. Wiąże się to $\mathrm{z}$ wyjątkowo szerokim zakresem podmiotów zobowiązanych do udostępniania posłom i senatorom informacji i wyjaśnień w sprawach wynikających z wykonywania obowiązków poselskich lub senatorskich. Zbiór ten obejmuje: członków Rady Ministrów oraz przedstawicieli właściwych organów i instytucji państwowych i samorządowych. W piśmiennictwie trafnie wskazuje się, że wynikające z tego przepisu obowiązki, odnoszą się obok administracji rządowej i samorządowej, również do: innych podmiotów państwowych, które znajdują się poza struktura administracji rządowej, a wykonuja zadania z zakresu administracji publicznej. W efekcie chodzi tu zarówno o organy administracji rzadowej, jak i te organy i instytucje, które niezależnie od rzadu realizuja funkcje z zakresu administracji, jak np. przedstawiciele Krajowej Rady Radiofonii i Telewizji. Ponadto również trzeba przyjąć, że podobne obowiązki dotycza także tych organów i instytucji państwowych, które organizacyjnie lub funkcjonalnie sa powiązane z parlamentem (np. Najwyższa Izba Kontroli). Nie ma natomiast podstaw do rozciagnięcia tego obowiązku na wszystkie organy władzy publicznej. Byłoby to nieuzasadnione, chociażby ze względu na możliwość naruszenia ich niezależności $[\ldots]^{8}$.

Charakterystyka prawna KNF (organu administracji państwowej - nierządowej) nie wiąże się z ograniczeniami, które wykluczałyby możliwość pozyskiwania przez posłów informacji i wyjaśnień w trybie art. 16 ust. 1 uw.m.p.s. Należy jednak podkreślić - po pierwsze - że czynności podejmowane przez posłów na

$8 \quad$ P. Uziębło, Uwagi do art. 16 [w:] K. Grajewski, J. Stelina, P. Uziębło, Komentarz do ustawy o wykonywaniu mandatu posła i senatora, Warszawa 2014, s. 220. 
podstawie omawianego przepisu powinny się wiązać z wykonywaniem mandatu poselskiego (senatorskiego) w Sejmie (Senacie). Dyrektywa argumentum a rubrica nakazuje przyjąć, że chodzi o „prawo” przysługujące posłom i senatorom w ramach działalności prowadzonej w izbach, których są członkami. Innymi słowy, chodzi o działania podejmowane indywidulanie w ramach kolegialnej aktywności Sejmu i Senatu.

Po drugie, zakres obowiązków wynikających $\mathrm{z}$ art. 16 ust. 1 u.wm.p.s. nie sięga tak „głęboko" jak prawo do informacji $\mathrm{z}$ art. 19 ust. 1 u.wm.p.s. W omawianym przypadku chodzi o „informacje i wyjaśnienia”, nie zaś uzyskiwanie „informacji i materiałów”, powiązane z prawem „wstępu do pomieszczeń", w których znajdują się te informacje i materiały, oraz „wglądem w działalność" kontrolowanego organu. Ramy prawne art. 16 ust. 1 ograniczają szczegółowość czynności kontrolnych podejmowanych na podstawie tego przepisu, ponieważ w praktyce pozostawiają dysponentowi informacji pełną kontrolę nad treścią przekazywanego komunikatu. Nie sposób uznać, że art. 19 ust. 1 stanowi konkretyzację uprawnienia, o którym mowa $\mathrm{w}$ art. 16 ust. 1, ponieważ przepisy te mają odmienne zakresy działania. Zbiór podmiotów podlegających obowiązkom, o którym mowa w art. 19 ust. 1, nie jest tożsamy ze zbiorem podmiotów podlegających obowiązkom, o których mowa w art. 16 ust. 1 (zakresy tych zbiorów przecinają się). Krytykowana wykładnia prowadziłaby do poszerzenia uprawnień kontrolnych wynikających $\mathrm{z}$ art. 16 ust. 1 wbrew ograniczeniom wynikającym z interpretacji literalnej.

\section{Podsumowanie}

Podstawą prawną czynności kontrolnych podejmowanych indywidualnie przez posła wobec KNF może być art. 16 ust. 1 u.w.m.p.s. Przepis ten pozwala na uzyskiwanie „informacji i wyjaśnień w sprawach wynikających $\mathrm{z}$ wykonywania obowiązków poselskich" od przedstawicieli właściwych organów państwowych, w tym również KNF. Czynności podejmowane przez posłów na podstawie art. 16 ust. 1 powinny wiązać się z kolegialną aktywnością Sejmu lub jego organów.

\section{Bibliografia}

Jurkowska-Zeidler A., Status prawny Komisji Nadzoru Finansowego jako organu administracji publicznej $w$ świetle wyroku Trybunału Konstytucyjnego z dnia 15 czerwca 2011 r., „Gdańskie Studia Prawnicze” 2012, nr 2.

Ochwat M., Status prawny Komisji Nadzoru Finansowego, „Monitor Prawa Bankowego” 2015, nr 7-8.

Uziębło P., Uwagi do art. 16 [w:] K. Grajewski, J. Stelina, P. Uziębło, Komentarz do ustawy o wykonywaniu mandatu posła i senatora, Warszawa 2014. 